\title{
Two species of Phytopythium (Pythiaceae, Pythiales) new to China
}

\begin{abstract}
Two oomycetes, Phytopythium mercuriale and Pp. sindhum were found in southern China, and they are newly recorded in China. These two species were both isolated from roots of soybean. $P p$. mercuriale is characterized by subglobose sporangia with conspicuous apical papillae, and occasionally forming oogonia. And $P p$. sindhum is identified from other Phytopythium species by its globose to sub-globose sporangia with conspicuous apical papillae, large and smooth oogonia, monoclinous or diclinous antheridia, and plerotic or nearly plerotic and thick-walled oospores. Illustrations and descriptions of the two new records are provided based on the materials from China.
\end{abstract}

Keywords: Coxl, ITS, Oomycota, Phytopythium mercuriale, Phytopythium sindhum
Volume 7 Issue 5 - 2019

\author{
Jia-Jia Chen, ${ }^{1,2}$ Hui Feng,' Xiaobo Zheng' \\ 'Department of Plant Pathology, Nanjing Agricultural University, \\ China \\ ${ }^{2}$ College of Landscape Architecture, Jiangsu Vocational College \\ of Agriculture and Forestry, China
}

Correspondence: Xiaobo Zheng, Department of Plant Pathology, Nanjing Agricultural University, Nanjing 210095, China,Tel 18362090654, Email xbzheng@njau.edu.cn

Received: August 09, 2019 | Published: September 16, 2019
Abbreviations: BI, bayesian inference; BPP, bayesian posterior probabilities; BT, bootstrap; CMA, corn meal agar; CI, consistency index; Coxl, cytochrome c oxidase subunit 1; GTR, general time reversible; HI, homoplasy index; ITS, the internal transcribed spacer; MP, maximum parsimony; MPT, maximum parsimonious tree; NJAU, the College of Plant Protection, Nanjing Agricultural University; PCA, potato carrot agar; PCR, the polymerase chain reaction; RC, rescaled consistency index; RI, retention index; TL, descriptive tree statistics tree length.

\section{Introduction}

The genus Phytopythium Abad et al., formerly classified as Pythium K-clade, ${ }^{1}$ was recently separated from Pythium $^{2}$ and typified by $P p$. sindhum A.M. Lodhi, Shahzad \& Lévesque. The principal characteristics of this genus include a combination of hyaline and coenocytic hyphae without septa, ovoid to globose sporangia with papillae (except for Pp. vexans (de Bary) Abad), common internal proliferation that is similar to that in the Phytophthora, zoospores that develop in a vesicle and form at the tip of a discharge tube from the sporangium like in Pythium, smooth oogonia, and paragynous antheridia. ${ }^{3-5}$ Phytopythium spp. are cosmopolitan and represent a range of functional groups, such as saprophytes in natural environments and plant pathogens ${ }^{6}$ and following recent taxonomic revisions ${ }^{7-9}$ and discoveries, ${ }^{5,6,10} 21$ species are recognized worldwide. During studies on the occurrence and diversity of oomycetes associated with soybean in Huang-Huai area of China, two new Chinese record of Phytopythium were identified from our isolates based on morphological characters and molecular phylogenetic analyses of ITS regions of the ribosomal RNA and mitochondrial Coxl sequence data. These two species are described in this work. Moreover, comparisons of the two species and their morphological and/or phylogenetically related species are also provided.

\section{Materials and methods}

\section{Isolates}

The cultures (Chen $265 \&$ Chen 314) of Phytopythium species were isolated from roots of soybean in Jiangsu and Anhui provinces in China. The isolation procedure followed the method described by Benard \& Punja. ${ }^{11}$ Pieces of tissue $5-10 \mathrm{~mm}$ were cut from the roots, washed in tap water and superficially dried on a paper towel, and plated on CMA containing rifampicin $(50 \mathrm{mg} / \mathrm{L})$, phenamacril $(5 \mathrm{mg} / \mathrm{L})$, ampicillin $(50 \mathrm{mg} / \mathrm{L})$, and pentachloronitrobenzene $(50 \mathrm{mg} / \mathrm{L})$ and incubated at $25^{\circ} \mathrm{C}$ for $2-3 \mathrm{~d}$. When mycelial growth was observed, purification was carried out by cutting a small piece of medium with mycelia at the edge of a colony, and transferring the cutted part into the new medium plates. ${ }^{12}$

\section{Morphology and growth rate}

The studied cultures were deposited in the herbaria of NJAU. The purified isolates were grown on CMA for morphological studies. Isolates were transferred to sterilized distilled water for sporulation. Fifty measurements were taken for each morphological feature, such as sporangia, oogonia and oospores. The cardinal temperatures were examined on PCA according to the method of van der PlaätsNiterink, ${ }^{3}$ and growth rates were measured at $24 \mathrm{~h}$ incubation. Each isolate was incubated at $5-40^{\circ} \mathrm{C}$ with intervals of $5^{\circ} \mathrm{C}$ on PCA media. When no growth was observed, the intervals were reduced from 5 to 2 or $1^{\circ} \mathrm{C}$ and the culture was returned to room temperature to check the revival of the growth.

\section{Molecular phylogeny}

DNA extraction, amplification, sequencing and sequence alignment

A cetyl trimethylammonium bromide rapid plant genome extraction kit (Demeter Biotechnologies Co., Ltd, Beijing) was used to extract total genomic DNA from purified isolates, and performed PCR according to the manufacturer's instructions with some modifications..$^{13}$ The ITS region was amplified with the primers: ITS4 and ITS5..$^{14}$ The Coxl gene was amplified with the primers: OomCoxI-Levlo (CYTCHGGRTGWCCRAAAAACCAAA) and OomCoxI-Levup (TCAWCWMGATGGCTTTTTTCAAC). ${ }^{15}$ The PCR procedure for ITS was as follows: initial denaturation at $95^{\circ} \mathrm{C}$ for 3 min, followed by 35 cycles at $94^{\circ} \mathrm{C}$ for $40 \mathrm{~s}, 54^{\circ} \mathrm{C}$ for $45 \mathrm{~s}$ and $72^{\circ} \mathrm{C}$ for $1 \mathrm{~min}$, and a final extension of $72^{\circ} \mathrm{C}$ for $10 \mathrm{~min}$. The PCR procedure for Cox 1 was as follows: initial denaturation at $94^{\circ} \mathrm{C}$ for $2-5 \mathrm{~min}$, 
followed by 35 cycles at $94^{\circ} \mathrm{C}$ for $30 \mathrm{~s}, 52^{\circ} \mathrm{C}$ for $30 \mathrm{~s}$ and $72^{\circ} \mathrm{C}$ for $1-2$ min, and a final extension of $72^{\circ} \mathrm{C}$ for $5-10 \mathrm{~min} .{ }^{16} \mathrm{The}$ PCR products were purified and sequenced in Genscript company (Nanjing, China) with the same primers.
Sequences generated in this study were aligned with additional Phytopythium sequences downloaded from GenBank (Table 1) using Clustal $\mathrm{X}^{17}$ and manually adjusted in BioEdit. ${ }^{18}$ Sequence alignment was deposited at TreeBase (http://purl.org/phylo/treebase; submission ID S24904).

Table I A list of species, cultures, and GenBank accession numbers of sequences used in this study

\begin{tabular}{|c|c|c|c|c|}
\hline \multirow{2}{*}{ Species name } & \multirow{2}{*}{ Isolate no. } & \multirow{2}{*}{ Geographic origin } & \multicolumn{2}{|l|}{ GenBank accession no. } \\
\hline & & & ITS rDNA & Coxl mtDNA \\
\hline Phytopythium aichiense & CBSI37I95 & Japan & AB948I97 & AB948I9I \\
\hline Pp. boreale & CBS55I.88 & China & AB725879 & AB690647 \\
\hline Pp. carbonicum & CBSIII2544 & France & $A B 725876$ & $A B 690648$ \\
\hline Pp. chamaehyphon & CBS259.30 & USA & AB690609 & AB690644 \\
\hline Pp. citrinum & CBSII9I7I & France & AYI97328 & AB690649 \\
\hline Pp. delawarense & $382 B$ & USA & $A B 725875$ & AB690642 \\
\hline Pp. fagopyri & CBS293.35 & Japan & AB690617 & AB69064I \\
\hline Pp. helicoides & CBS286.3I & USA & $A B 725878$ & $A B 690645$ \\
\hline Pp. iriomotense & CBSI37I04 & Japan & AB690629 & AB690659 \\
\hline Pp. kandeliae & CBS 113.91 & China & KJ39996I & KJ690245 \\
\hline Pp. litorale & CBS 118360 & Germany & HQ643386 & HQ708433 \\
\hline Pp. mercuriale & CBSI 22443 & South Africa & AB725882 & AB690636 \\
\hline Pp. mercuriale & Chen $314^{*}$ & China & MN266879 & MN27I 343 \\
\hline Pp. mirpurense & CBSI 24523 & Pakistan & $\mathrm{KJ} 831613$ & $\mathrm{KJ} 831612$ \\
\hline Pp. montanum & CBSIIII349 & Germany & AB725883 & AB690637 \\
\hline Pp. nanjingense & Chen 172 & China & MF459634 & MF45963I \\
\hline Pp. oedochilum & CBS292.37 & USA & HQ643392 & HQ708439 \\
\hline Pp. ostracodes & CBS 768.73 & Spain & HQ643395 & HQ708442 \\
\hline Pp. sindhum & CBSI245I8 & Pakistan & HM244825 & HQ708443 \\
\hline Pp. sindhum & Chen $265^{*}$ & China & MF984II I MF984I49 & MF984I49 \\
\hline Pp. vexans & CBSII 9.80 & Iran & HQ643400 & HQ708447 \\
\hline Pythium dimorphum & CBS406.72 & USA & HQ643525 & HQ70857I \\
\hline Py. ultimum & CBS398.5I & Netherlands & HQ643865 & HQ708906 \\
\hline
\end{tabular}

*New sequences determined in the present study

\section{Phylogenetic analyses}

Phylogenetic analysis was done as in Chen \& Cui. ${ }^{19}$ MP analysis was applied to the combined dataset of ITS-Coxl sequences. Pythium dimorphum F.F. Hendrix \& W.A. Campb. and Py. ultimum Trow were used as outgroups. ${ }^{7}$ The tree construction procedure was performed in PAUP* version $4.0 \mathrm{~b} 10 .^{20}$ All characters were equally weighted and gaps were treated as missing data. Trees were inferred using the heuristic search option with TBR branch swapping and 1000 random sequence additions. Max-trees were set to 5000, branches of zero length were collapsed and all parsimonious trees were saved. Clade robustness was assessed using a BT analysis with 1000 replicates. ${ }^{21}$ TL, CI, RI, RC, and HI were calculated for each MPT generated. Phylogenetic trees were visualized using Treeview. ${ }^{22}$

MrModeltest2.3 $3^{23}$ was used to determine the best-fit evolution model for BI. BI of the dataset was calculated with MrBayes3.1.2 (Ronquist and Huelsenbeck 2003) with a GTR model of DNA substitution and an inverse gamma distribution rate variation across sites. Four Markov chains were run for 2 runs from random starting trees for 2 million generations of the two combined datasets, and trees were sampled every 100 generations. The burn-in was set to discard the first $25 \%$ of the trees. A majority rule consensus tree of all remaining trees was calculated. Branches that received bootstrap support for MP and BPP greater than or equal to $75 \%(\mathrm{MP})$ and 0.95 (BPP) respectively were considered as significantly supported.

\section{Results and discussions}

\section{Molecular phylogeny}

The combined ITS + Coxl dataset of Phytopythium species included sequences from 23 isolates representing 21 taxa. The dataset had an aligned length of 1623 characters, of which 850 characters are constant, 206 are variable and parsimony-uninformative, and 567 are parsimony-informative. Maximum parsimony analysis yielded one equally parsimonious tree $(\mathrm{TL}=2214, \mathrm{CI}=0.595, \mathrm{RI}=0.592$, $\mathrm{RC}=0.352, \mathrm{HI}=0.405)$. Best model for the combined ITS + CoxI 
sequences dataset estimated and applied in the Bayesian analysis: $\mathrm{GTR}+\mathrm{I}+\mathrm{G}$, lset $\mathrm{nst}=6$, rates $=$ invgamma; prset statefreqpr $=$ dirichlet $(1,1,1,1)$. Bayesian analysis resulted in the same topology with an average standard deviation of split frequencies $=0.003061$. The Chinese isolates Chen $265 \&$ Chen 314 were identical to the authorized sequences of Phytopythium mercuriale and Pp. sindhum available in GenBank and thus clustered within clades representing $P p$. mercuriale, and $P p$. sindhum with high supporting values $(100 \%$ $\mathrm{MP}$ and $1 \mathrm{BPPs}$, Figure 1), respectively.

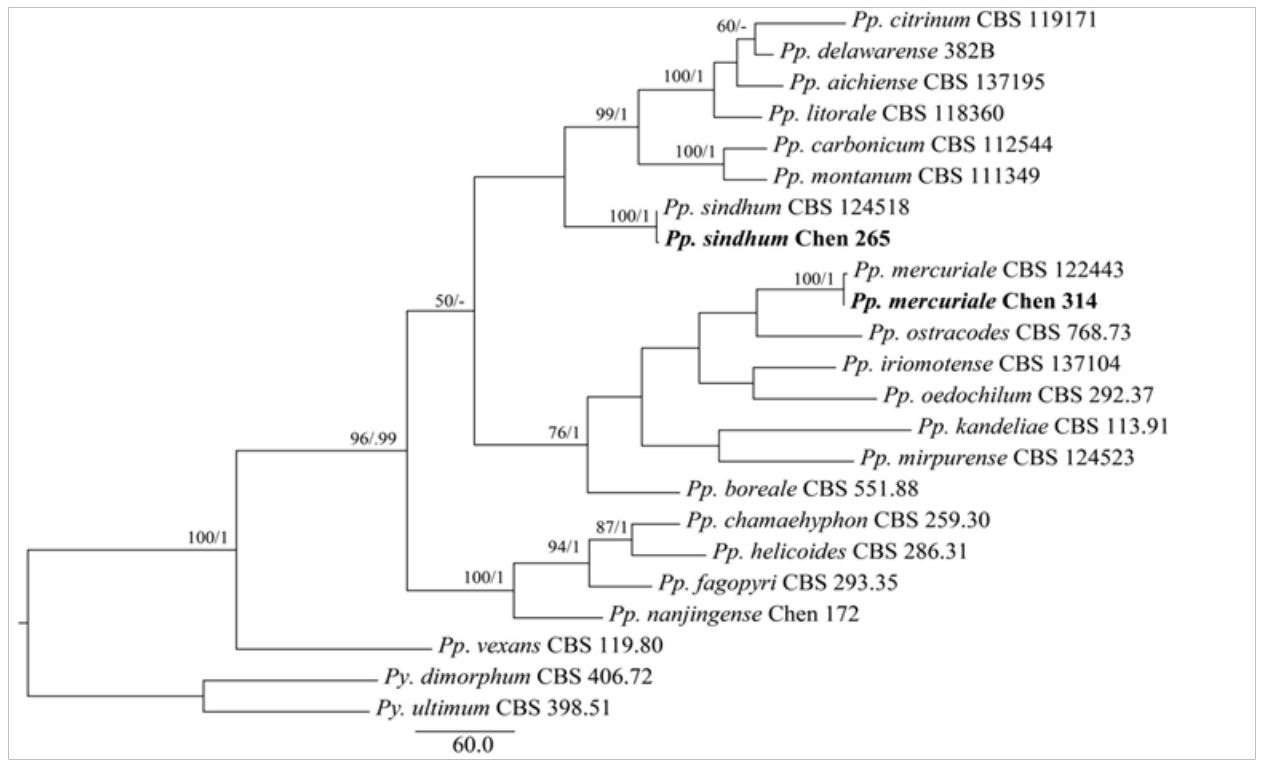

Figure I Phylogeny of species in Phytopythium and related species generated by maximum parsimony based on ITS-Cox I sequence data. Branches are labeled with parsimony bootstrap proportions (before slanting line) high than $50 \%$ and Bayesian posterior probabilities (after slanting line) more than 0.95. Pp. refers to Phytopythium, and Py. refers to Pythium.

\section{Taxonomy}

Phytopythium mercuriale (Belbahri, B. Paul \& Lefort) Abad et al., Persoonia 34: 37, 2014 Figure 2

Colonies submerged, with stellate pattern on CMA. Average growth rates $3 \mathrm{~mm}$ day $^{-1}$ at $5^{\circ} \mathrm{C}, 7 \mathrm{~mm}^{-1 a y}{ }^{-1}$ at $10^{\circ} \mathrm{C}, 10 \mathrm{~mm}^{-1 a y}{ }^{-1}$ at $15^{\circ} \mathrm{C}, 12 \mathrm{~mm}^{-1 a y}{ }^{-1}$ at $20^{\circ} \mathrm{C}, 15 \mathrm{~mm} \mathrm{day}^{-1}$ at $25^{\circ} \mathrm{C}_{1} 16 \mathrm{~mm}^{-1 a y}{ }^{-1}$ at $30^{\circ} \mathrm{C}$, $10 \mathrm{~mm}$ day $^{-1}$ at $35^{\circ} \mathrm{C}$, but when returned to room temperature both of them started to grow again. Cardinal temperatures: minimum $4^{\circ} \mathrm{C}$, optimum $25-30^{\circ} \mathrm{C}$, maximum $38^{\circ} \mathrm{C}$. Main hyphae hyaline, aseptate, up to $6.0 \mu \mathrm{m}$ wide. No hyphal swellings. Sporangia subglobose, terminal with conspicuous apical papillae, proliferation external, internal and internally nested, $18-28 \times 20-30 \mu \mathrm{m}$ (mean $25 \times 26 \mu \mathrm{m}$ ) in diameter. Oogonia globose, smooth, $25-40 \mu \mathrm{m}$ (mean $33 \mu \mathrm{m}$ ) in diameter. Antheridia not observed. Oospores plerotic, globose, 23$38 \mu \mathrm{m}$ (mean $31 \mu \mathrm{m})$ in diameter, hyaline. Oospore wall thin, $0.5-$ $1.5 \mu \mathrm{m}$ (mean $1 \mu \mathrm{m})$ thick.

Specimen examined: CHINA. Anhui Province, Bengbu, from Glycine max, 28 Sep 2017, J.J. Chen, Chen 314 (NJAU).

Remarks: Phytopythium mercuriale may be confused with $P p$. boreale $^{24} \mathrm{Abad}$ et al. in having lacking for antheridia and plerotic oospores, but the latter species has smaller oospores (av. $22.2 \mu \mathrm{m}$, Duan 1985, Table 2). In addition, $P p$. boreale is distant from $P p$. mercuriale in the phylogenetic analysis (Figure 1).
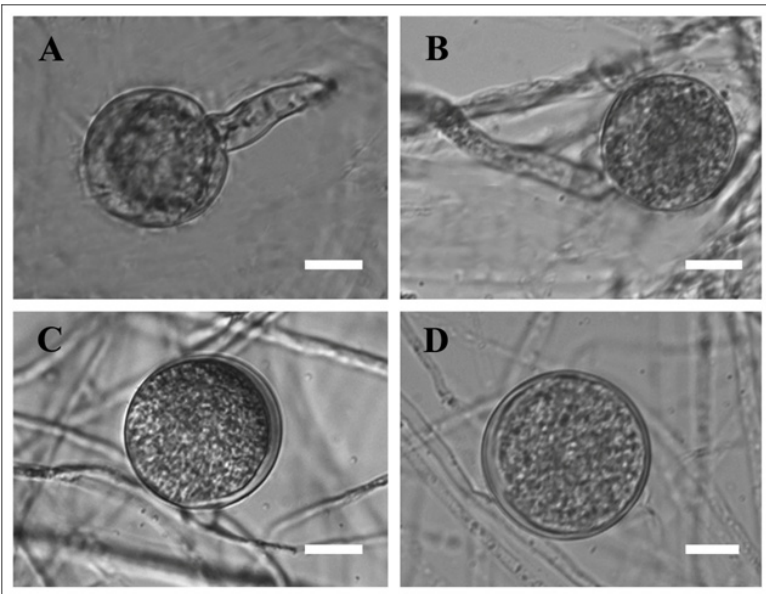

Figure 2 Asexual and sexual reproductive bodies of Phytopythium mercuriale (Chen 314). A-B, Subglobose sporangia with conspicuous apical papillae; C-D, Globose oogonia with plerotic oospores; Scale bars A-D $=10 \mu \mathrm{m}$. 
Table 2 Morphological description of Phytopythium mercuriale, Pp. sindhum and the most closely related species

\begin{tabular}{|c|c|c|c|c|c|}
\hline & $\begin{array}{l}\text { Pp. mercuriale (Chen } \\
3 \mid 4 \text { ) }\end{array}$ & $\begin{array}{l}\text { Pp. sindhum (Chen } \\
\text { 265) }\end{array}$ & Pp. boreale & $\begin{array}{l}\text { Pp. oedochilum } \\
\text { (Drechsler) Abad } \\
\text { et al. }\end{array}$ & Pp. ostracodes \\
\hline Sporangia & Subglobose & $\begin{array}{l}\text { Globose to } \\
\text { subglobose }\end{array}$ & Absent & $\begin{array}{l}\text { Subglobose, } \\
\text { lemoniform, obovoid } \\
\text { or ovoid, }\end{array}$ & $\begin{array}{l}\text { Globose to } \\
\text { subglobose }\end{array}$ \\
\hline Hyphal swelling & Absent & Absent & Present & Absent & Absent \\
\hline Proliferation & $\begin{array}{l}\text { External, internal and } \\
\text { internally nested }\end{array}$ & $\begin{array}{l}\text { External, internal } \\
\text { and internally } \\
\text { nested }\end{array}$ & Internal & $\begin{array}{l}\text { External, internal and } \\
\text { internally nested }\end{array}$ & $\begin{array}{l}\text { External, internal } \\
\text { and internally } \\
\text { nested }\end{array}$ \\
\hline Antheridia & Not observed & $\begin{array}{l}\text { Monoclinous as } \\
\text { well as diclinous }\end{array}$ & Absent & $\begin{array}{l}\text { Mostly diclinous, } \\
\text { occasionally } \\
\text { monoclinous }\end{array}$ & $\begin{array}{l}\text { Mostly } \\
\text { monoclinous, rarely } \\
\text { diclinous }\end{array}$ \\
\hline Oospores $(\mu \mathrm{m})$ & Plerotic av. 3I & $\begin{array}{l}\text { Plerotic or nearly } \\
\text { plerotic, av. } 34\end{array}$ & Plerotic, av. 22.2 & Aplerotic, av. 30.3 & $\begin{array}{l}\text { Plerotic or nearly } \\
\text { plerotic, av. } 32.5\end{array}$ \\
\hline Cardinal temperature & $\begin{array}{l}\text { Min } 4^{\circ} \mathrm{C} \text {, optimum } \\
25-30^{\circ} \mathrm{C} \text { and max } \\
38^{\circ} \mathrm{C}\end{array}$ & $\begin{array}{l}\text { Min } 5^{\circ} \mathrm{C} \text {, optimum } \\
30^{\circ} \mathrm{C} \text { and max } \\
38^{\circ} \mathrm{C}\end{array}$ & $\begin{array}{l}\text { Min } 4^{\circ} \mathrm{C} \text {, } \\
\text { optimum } 25- \\
31^{\circ} \mathrm{C} \text { and max } \\
43^{\circ} \mathrm{C}\end{array}$ & $\begin{array}{l}\text { Min } 10^{\circ} \mathrm{C} \text {, optimum } \\
30^{\circ} \mathrm{C} \text { and } \max 35^{\circ} \mathrm{C}\end{array}$ & $\begin{array}{l}\text { Min } 10^{\circ} \mathrm{C} \text {, optimum } \\
30^{\circ} \mathrm{C} \text { and } \max \\
35^{\circ} \mathrm{C}\end{array}$ \\
\hline $\begin{array}{l}\text { Daily growth rates on } \\
\text { PCA at } 25^{\circ} \mathrm{C}(\mathrm{mm})\end{array}$ & I5/per day & I4/per day & 20/per day & 20/per day & 8/per day \\
\hline Reference & This study & This study & Duan (1985) & $\begin{array}{l}\text { Van der Plaats- } \\
\text { Niterink (198I) }\end{array}$ & $\begin{array}{l}\text { Van der Plaats- } \\
\text { Niterink (198I) }\end{array}$ \\
\hline
\end{tabular}

Phytopythium sindhum A.M. Lodhi, Shahzad \& Lévesque, Persoonia 24: 137, 2010 Figure 3

Colonies submerged, with rosette pattern on CMA. Average growth rates $3 \mathrm{~mm}$ day ${ }^{-1}$ at $10^{\circ} \mathrm{C}, 5 \mathrm{~mm}$ day $^{-1}$ at $15^{\circ} \mathrm{C}, 7 \mathrm{~mm}$ day $^{-1}$ at $20^{\circ} \mathrm{C}, 14 \mathrm{~mm}^{-1 a y^{-1}}$ at $25^{\circ} \mathrm{C}, 17 \mathrm{~mm} \mathrm{day}^{-1}$ at $30^{\circ} \mathrm{C}, 12 \mathrm{~mm}$ day $^{-1}$ at $35^{\circ} \mathrm{C}$, but when returned to room temperature both of them started to grow again. Cardinal temperatures: minimum $5^{\circ} \mathrm{C}$, optimum $30^{\circ} \mathrm{C}$, maximum $38^{\circ} \mathrm{C}$. Main hyphae hyaline, aseptate, up to $6.0 \mu \mathrm{m}$ wide. No hyphal swellings. Sporangia globose to sub-globose, terminal with conspicuous apical papillae and internal nested or internal extended proliferation, $20-50 \times 12.5-37.5 \mu \mathrm{m}$ (mean $32.5 \times 25.5 \mu \mathrm{m})$ in diameter. Zoospores formed in sterile water at $25^{\circ} \mathrm{C}$, Encysted

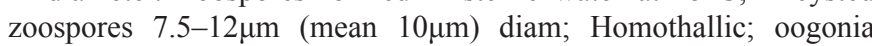
globose, smooth, terminal, $30-40 \mu \mathrm{m}$ (mean $35 \mu \mathrm{m}$ ) in diameter. Antheridia monoclinous or diclinous, one to two per oogonium; antheridial stalks unbranched; antheridial cells elongate, more or less lengthwise applied but crook necked, making narrow apical contact with the oogonium. Oospores plerotic or nearly plerotic, globose, $30-38 \mu \mathrm{m}$ (mean $34 \mu \mathrm{m})$ in diameter, hyaline. Oospore wall very thick, $4.5-6.5 \mu \mathrm{m}$ (mean $5.5 \mu \mathrm{m})$ thick.
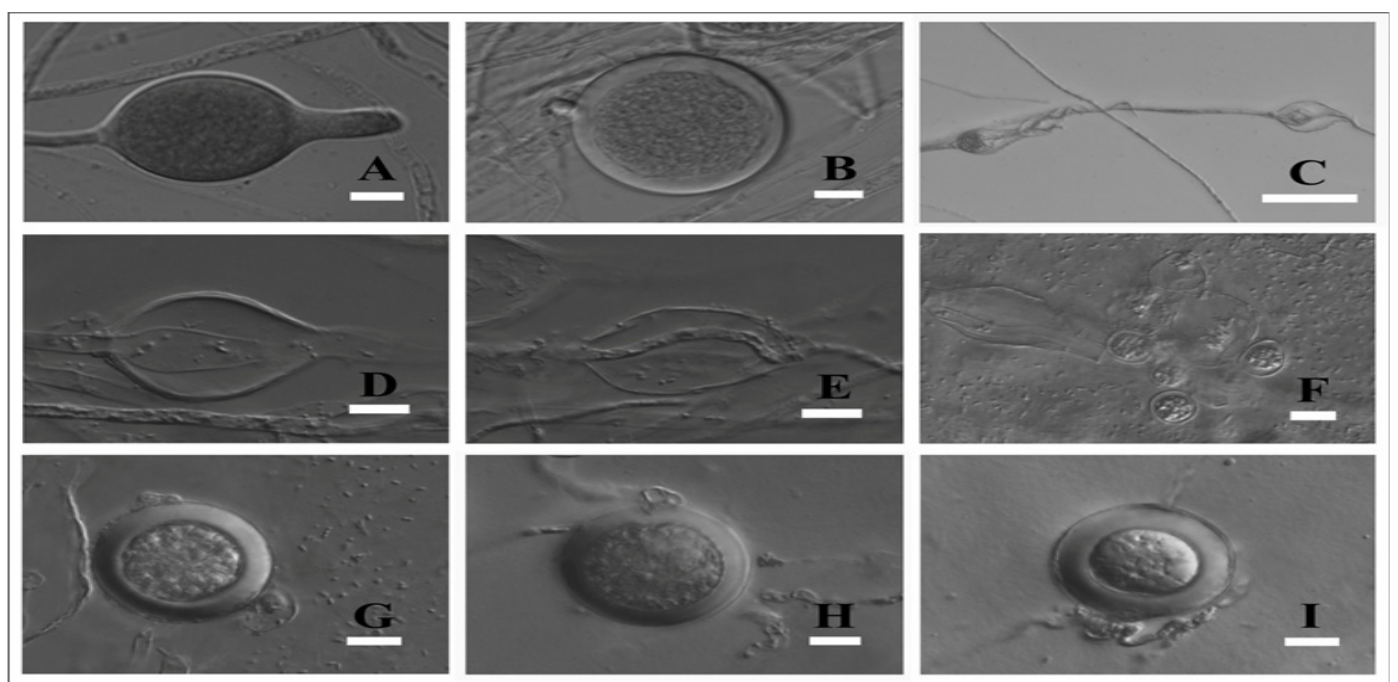

Figure 3 Asexual and sexual reproductive bodies of Phytopythium sindhum (Chen 265). A, Sub-globose sporangium with conspicuous apical papillae; B, Globose sporangium with short stalk; C-E, Internally nested proliferation and internal proliferation; F, Zoospore development; G, Plerotic oospore and two antheridia; $\mathrm{H}$, Monoclinous antheridum; I, Diclinous antheridum; Scale bars C $=5 \mu \mathrm{m}, \mathrm{A}-\mathrm{B} \& \mathrm{D}-\mathrm{J}=10 \mu \mathrm{m}$. 
Specimen examined: CHINA. Jiangsu Province, Xuzhou, from Glycine max, 23 Aug 2016, J.J. Chen, Chen 265 (NJAU).

Remarks: Phytopythium sindhum is easily identified by its globose to sub-globose sporangia with conspicuous apical papillae, large and smooth oogonia, monoclinous or diclinous antheridia, and plerotic or nearly plerotic and thick-walled oospores. It is related to $P p$. ostracodes (Drechsler) Abad et al., which also produces globose to sub-globose sporangia but differs in diclinous, occasionally monoclinous and relatively slow growth $\left(8 \mathrm{~mm} \mathrm{~d}^{-1}\right) \cdot{ }^{26}$ Phylogenetically two cultures of $P p$. sindhum clustered together with strong supports (100\% ML, 1.0 BPPs, Figure 1) and occurred on a single branch and are distant from other species of Phytopythium.

\section{Conclusion}

In this study, we analyzed the phylogenetics of 19 previously accepted species of Phytopythium. With the aid of morphology and phylogenetic analyses of the phylogeny of ITS and Coxl genes, two new Chinese record, Phytopythium mercuriale and Pp. sindhum are described. Moreover, comparisons of the two new Chinese record and their morphological and/or phylogenetically related species are also provided in Table 2. Rot diseases constitute a serious challenge to soybean production. Root, seed and seedling rots in soybean in China often shows as a complex caused by several pathogenic fungi (e.g., Fusarium graminearum Schwabe, F. culmorum (Wm.G. Sm.) Sacc., and Rhizoctonia solani J.G. Kühn) and the oomycete Phytophthora sojae Kaufm. \& Gerd. and Pythium ultimum Trow, ${ }^{25}$ and may also be associated with plant-parasitic nematodes individually or in any possible combination. ${ }^{26,27}$ This study significantly improved our understanding of the rare oomycetes genera Phytopythium associated with soybean from China. The two species obtained from this study may potentially be highly valuable. However, because little was known about the role or importance of Phytopythium spp. in disease on soybean in China. Thus, a further study was undertaken to determine the identity, role, pathogenicity, and virulence of Phytopythium spp. associated with soybean in the future.

\section{Acknowledgments}

The research was supported by the National Natural Science Foundation of China (31601618), the Fundamental Research Funds for the Central Universities (KJQN201738), and the Natural Science Foundation of Jiangsu Province (BK20160737).

\section{Conflicts of interest}

Authors declare that there is no conflict of interest.

\section{References}

1. Bala K, Robideau GP, Lévesque A, et al. Phytopythium sindhum Lodhi, Shahzad \& Levesque, sp. nov. Persoonia. 2010;24:127-139.

2. Pringsheim N. Contributions to the morphology and classification of algae. 2. The Saprolegníeen. Yearbooks for Scientific Botany. 1858;1:284-306.

3. van der Plaäts-Niterink AJ. Monograph of the genus Pythium. Studies in Mycology. 1981;21:1-242.

4. Thines M. Phylogeny and evolution of plant pathogenic oomycetes-a global overview. European Journal of Plant Pathology. 2014;138(3):431447

5. Baten MA, Mingzhu L, Motohashi K, et al. Two new species, Phytopythium iriomotense sp. nov. and $\mathrm{P}$. aichiense $\mathrm{sp}$. nov., isolated from river water and water purification sludge in Japan. Mycological Progress. 2015;14:1-12.
6. Baten MA, Asano T, Motohashi K, et al. Phylogenetic relationships among Phytopythium species, and re-evaluation of Phytopythium fagopyri comb. nov., recovered from damped-off buckwheat seedlings in Japan. Mycological Progress. 2014;13:1145-1156.

7. de Cock AWAM, Lodhi AM, Rintoul TL, et al. Phytopythium: molecular phylogeny and systematics. Persoonia. 2015;34:25-39.

8. de Jesus AL, Gonçalves DR, Rocha SCO, et al. Morphological and phylogenetic analyses of three Phytopythium species (Peronosporales, Oomycota) from Brazil. Cryptogamie Mycologie. 2016;37(1):117-128.

9. Bennett RM, de Cock AW, Lévesque CA, et al. Calycofera gen. nov., an estuarine sister taxon to Phytopythium, Peronosporaceae. Mycological Progress. 2017;16(10):947-954.

10. Chen JJ, Feng H, Wang YC, et al. Phytopythium nanjingernse sp. nov. (Pythiaceae, Peronosporales) from southern China based on morphological and molecular characters. Phytotaxa. 2019;403(3):239-247.

11. Benard D, Punja ZK. Role of Pythium species in cavity spot development on carrots in British Columbia. Canadian Journal of Plant Pathology. 1995; 17(1):31-45.

12. Long YY, Wei JG, Sun X, et al. Two new Pythium species from China based on the morphology and DNA sequence data. Mycological Progress. 2012;11(3):689-698.

13. Chen JJ, Lu L, Ye WW, et al. Pythium cedri sp. nov. (Pythiaceae, Pythiales) from southern China based on morphological and molecular characters. Phytotaxa. 2017;309(2):135-142.

14. White TJ, Bruns T, Lee S, et al. Amplification and direct sequencing of fungal ribosomal RNA genes for phylogenetics. In: Innis MA, Gelfand $\mathrm{DH}$, Sninsky JJ, et al. (Eds) PCR protocols: a guide to methods and applications (eds.). San Diego: Academic Press; 1990. 315-322 p.

15. Robideau GP, de Cock AW, Coffey MD, et al. DNA barcoding of oomycetes with cytochrome c oxidase subunit I and internal transcribed spacer. $\mathrm{Mol}$ Ecol Resour. 2011;11(6):1002-1011.

16. Blair JE, Coffey MD, Park SY, et al. A multi-locus phylogeny for Phytophthora utilizing markers derived from complete genome sequences. Fungal Genet Biol. 2008;45(3):266-277.

17. Thompson JD, Gibson TJ, Plewniak F, et al. The CLUSTAL X windows interface: flexible strategies formultiple sequence alignment aided by quality analysis tools. Nucleic Acids Res. 1997;25(24):4876-4882.

18. Hall TA. Bioedit: a user-friendly biological sequence alignment editor and analysis program for windows 95/98/NT. Nucleic Acids Symposium Series. 1999;41:95-98.

19. Chen JJ, Cui BK. Phlebiporia bubalina gen. et. sp. nov. (Meruliaceae, Polyporales) from Southwest China with a preliminary phylogeny based on rDNA sequences. Mycological Progress. 2014;13(3):563-573.

20. Swofford DL. PAUP*: phylogenetic analysis using parsimony (*and other methods), Version 4.0b10. Sunderland: Sinauer Associates; 2002.

21. Felsenstein J. Confidence limits on phylogenetics: an approach using bootstrap. Evolution. 1985;39(4):783-791.

22. Page RDM. TREEVIEW: application to display phylogenetic trees on personal computers. Comput Appl Biosci. 1996;12(4):357-358.

23. Nylander JAA. MrModeltest v2. Program distributed by the author. Uppsala: Evolutionary Biology Centre, Uppsala University; 2004.

24. Duan RL. A new species and two new records of Pythium in China. Acta Mycologica Sinica. 1985;4:1-4.

25. Zeng DD, Ye WW, Xu M, et al. Rapid diagnosis of soya bean root rot vaused by Fusarium culmorum using a loop-mediated isothermal amplification assay. Journal of Phytopathology. 2017;165(4):249-256. 
26. Wang DG, Li K, Huang ZP, et al. Disease resistance evaluation of soybean cultivars (lines) in Huang-Huai-Hai. Plant Protection. 2014;40:144-149.
27. Li MH, Wang YY, Chen JS, et al. Incidence and Disease Index of Soybean Diseases in the Northeast of China in 2015. Soybean Science. 2016;35(4):643-648. 